\title{
IMPACT OF COVID-19 ON INTER-STATE MIGRANT WORKERS IN INDIA
}

\author{
Dr. Usha Rajagopalan \\ Assistant Professor, Prince Sultan University, Kingdom of Saudi Arabia. \\ Dr. Hebah Shaloob \\ Assistant Professor, Faculty of Applied Studies, Department of Accounting \\ King Abdulaziz University, Jeddah, Kingdom of Saudi Arabia
}

\begin{abstract}
The onset of the novel coronavirus (COVID-19) has led to the ongoing pandemic, which is wreaking havoc in the lives of humans without any discrimination. India, a highly populous country, is also raging a battle with the unknown enemy, unlike other countries in the world. India is currently faced with a peculiar situation, i.e., its interstate migrant workers, which form about $12 \%$ of the total migrant population in the country as per 2011 Census. This conceptual paper is intended to understand the condition of these inter-state migrant workers. This study also attempts to answer the following questions: What must be done to them and their employers? What could have been done to avoid the catastrophe altogether?
\end{abstract}

Key words: COVID-19; Census 2011; Migrant Population; Inter-State Migrants; Migrant Workers

Cite this Article: Usha Rajagopalan and Hebah Shaloob, Impact of Covid-19 on InterState Migrant Workers in India, International Journal of Management, 11(12), 2020, pp 3233-3238.

http://iaeme.com/Home/issue/IJM?Volume=11\&Issue=12

\section{INTRODUCTION}

The entire world is fighting a battle against the Novel Coronavirus, also named as COVID-19, which is an unknown enemy. This pandemic has derailed the entire population and had brought all activities to a grinding halt. All the countries in the world, except for a few countries across the African continent, were in a sort of house arrest, which was inexperienced even during World Wars I and II. India, as well, is no exception towards this pandemic, and the reaction from the Government had been the same as that of the other countries. As the number of infected people started picking up, the Government of India (GOI) brought in a forced lockdown on their citizens since the midnight of March $24^{\text {th, } 2020}$, giving the citizens just about 4 hours to equip themselves for a new experience in life (COVID-19 pandemic Wikipedia, 2020). In this process of fight against COVID-19, the GOI took a huge and calculated risk by bringing about 
an unprecedented lockdown in the world's second most populous country (estimated to be at around 1.30 billion people). For a country having around $22 \%$ of its population living below the poverty line, the consequences faced by them is beyond imagination (Migration, 2001).

\section{THE MIGRANT POPULATION}

As per the definition from the Census Department of the Country, any person who is not in his place of birth at the time of the enumeration is migrant (Sharma, 2020). A woman who gets married to a man in another district of the same state or another state is also considered to be either an intra-state migrant or inter-state migrant. However, in a large country like India, carrying out an accurate survey is a tedious job. Taking note of this, let us look at the available statistics with regards to the migrant population in India.

As per the 2001 census, the number of inter-state migrants in the country has been reported to be around 42 million, which is about $13 \%$ of the total migrants in the country. As per the 2011 Census, the inter-state migrants have been reported to be around 51 million, which is $12 \%$ of the total migrant population. As per the Economic Survey of Government of India for 20172018 , the total number of inter-state migrants is reported to be at around 81 million, and even a nominal growth rate of about 5\% could increase it to about 90 million in 2020 .

\section{MIGRANT WORKERS}

The lockdown announced by the GOI had a direct impact on the inter-state migrant population (hereafter, the migrant workers). A study by Supriyo De (2019), published in worldbank.org in 2019, reports that the internal migration in India has grown between 2001 and 2011, while the interstate migration remains almost at the same level, i.e., about $4 \%$ of the total population (COVID-19 pandemic, 2019; Migration, 2001; Sharma, 2019; Supriyo De, 2019). Martin Bell, Elin Charles et al. (2015) report that the internal migration in India is the lowest among the 80 countries considered in the study. Another recent study by Basu (2020) on the impact of COVID-19 on migrant agricultural labor in India emphasizes the future of these laborers as there is a possibility of mechanization of farmland activities due to social distancing requirements being the workplace norms in future. Pullanoor (2020) opines that the internal and external migrant returnees could culminate into refugees in India, for which the country is not well prepared. A study by Dhal (2020) speaks about the precarious working conditions of migrant workers in informal construction activities across the country. His study deals with the situation where the workers assemble in groups at various locations to get hired by various agents for that day of work. The study by Agarwal and Chandrashekar (2016) discusses the disparity in the amount of wages among the migrant and local workers in the construction industry across India.

In a vast country like India with an enormous population, ensuring that all the eligible sections of the population are included in the scheme is near to impossible. This has always impeded with the migrant population. This migrant population is mostly the left-outs as they keep moving from place to place like nomads in search of better opportunities. The pandemic is the first of its type wherein the population is being directly affected in an unprecedented situation.

Even though the GOI has insisted the people of the country to stay where they were at the start of the lockdown, a portion of the migrant workers started feeling jittery. Migration within the country generally takes place for a better livelihood, i.e., from a rural-based economy to an urban economy. Other reasons for migration include marriage, education, health, etc. Migrant workers are majorly unskilled, and they mostly engage themselves in menial jobs based on daily wages. Only a section of migrant workers is skilled enough to be employed in organized sectors like manufacturing, construction, and service industries like the hospital industry. The GOI had 
enacted an Act in the year 1979 to protect the interests of all migrant workers and tweaked it in the year 2019 along with several outdated labor laws. However, the same is not being respected either by the employer or the authorities to whom the implementation of the law has been entrusted. The migrant workers are generally those who have moved out of their native villages, i.e., from the most backward states of India like Uttar Pradesh (UP) and Bihar. These two states account for almost $50 \%$ of the total migrant workers across the country, with the highest number of positive net out-migrant numbers within their credit. Other states like Odisha, Jharkhand, and Assam also have positive net out-migrants. These workers normally go to better developed states like Maharashtra, Gujarat, Delhi, etc. in search of better living.

As inferred earlier, considering the enormity of the country's size and population, getting a more detailed profile of migrant workers is an onerous job. Economics is generally a pull factor behind the migration of human population from one place to another. While the economic activity came to standstill, the country has been experiencing an exodus of desperate migrant workers returning to their place of domicile. This is despite the GOI insisting that the employers of migrant communities should take care of their workers by providing them necessities like food, shelter, and healthcare. Some migrant workers were taken care of by their employers, but not everyone was fortunate enough to be bestowed upon with their basic needs. The migrant working community was able to meet their daily chores for a few days with whatever little savings they had, if at all they had. Thereafter, they started getting impatient as the days started passing and with no signs of any improvement in the situation.

Even though the respective local state governments did their bit to satisfy and keep the migrant workers as comfortable as possible, the sheer number and the mass psychology of despair during unprecedented circumstances, like a pandemic not seen in a millennium, led to more disgruntlement. Thus, many migrant workers started heading back to their hometowns, resulting in a mass movement of humans ever since the independence of the country.

Once the situation was going out of control, the GOI organized for the mass movement of its migrant workers by arranging transports. As per a report from the Ministry of Railways on the $5^{\text {th }}$ of June 2020, a total of about 4000 trains had transported about 5.6 million migrant workers from different parts of the country back to their home states during May 2020. The migrant movement is continuing within the country; however, the demand for such trains has tapered down considerably in different parts of the country. Although there is continuous migrant movement even after the unwinding of the lockdown, we can consider that the desperate lot has already reached their destinations. Now, the real story of migrant workers and their erstwhile employers start. The country is coming out of the lockdown in phases, and the economic activity has slowly re-started in many parts of the country; however, the infection is still raging on unabated within the country.

\section{WHAT NEXT FOR THE STAKE HOLDERS}

The hapless situation in which the migrant workers were in was pathetic. The resultant mass movement of humans back to their villages gives rise to the following questions:

1. What next for these returnees?

2. What next for the employers who had employed them?

As it is obvious, the returnees had left their native places in search of a better living. Now, when they return to their hometowns again with an empty hand, how is the already straining rural economy going to take them in? The strain in the rural economy is evident in the dwindling rural demand over the last few years. The influx of returnees is going to reduce the bleak purchasing power of the rural population, thereby endangering the overall growth of the economy. How far and long is this situation getting along in their native places? How are they going to start a fresh life? What are the available avenues for them to earn a living? These 
questions will surely be in the minds of the returnees. Questions are all around, but whether they have a clear-cut answer to these questions remains doubtful.

Although the unwinding of economic activities has started in earnestness, it could take at least a few months to get back into top gear. How are the industries in different parts of the country going to cope up with the absence of migrant workers? Hereis another important question that appears before everyone: Are the returnees willing to get back to their erstwhile employers? If yes, then when? The trauma of hunger and the sight of death at a very close quarter would be playing in the minds of these poor people, and this could take quite some time to get healed. This phase could also be a blessing in disguise for both the employees and the employers. This is an opportunity to purge out the unfit from the lot on either side. It would have an impact on the overall productivity of the system. Those employers who were perceived to be not so human to the plight of their employees might get a hole in the balance sheet by way of a higher cost of labor and indifferent productivity.

\section{WHAT COULD HAVE BEEN DONE?}

What the stake holders could have done to avoid this situation is a major and pertinent question at this hour. The defunct Act of 1979 is a moot spectator to the plight of migrant laborers. The Act, which was enacted to protect the life of migrant laborers, was perceived to be more loaded to the welfare of migrant labors rather than the available talents locally. The stringent provisions of the Act have become the deterrent for employers, rendering it to be toothless. The scenario would have been entirely different if the Act were implemented in letter and spirit. The provisions of the Act were to give an identity to migrant workers, which they have missed out as the Act was not complied with either by the employers or the powers that be.

The situation could have been avoided if migrant workers' basic needs were met at the last mile connectivity levels: firstly, by the employers, secondly by the local district, and thirdly, by the respective state governments. In this regard, a few local governments performed well and tried to retain their workers up to a certain extent even though they could not satisfy everyone. But, in other places, the situation was entirely different as the migrant workers started feeling increasingly insecure.

The plight of the working community must be viewed from an entirely different perspective as they started feeling alienated in their own country. 'Pathetic' is more a simpler term to explain their plight, although the simple but more potent 'mass psychology' had a major role in the whole scenario. When the push for returning home started at one part of the country, it got caught like wildfire all over the country. The people, even though it is difficult, should have been a little more patient. Also, the local authorities should have shown more human face to the migrant workers and acted in a manner to gain their confidence in their interest of their local economy.

Moreover, the GOI could have taken certain precautions and given strict guidelines to respective state governments in this regard. One major task for the local governments could have been the continuous supply of basic food grains to the workers. This did not happen, and the workers were left to the mercy of others like NGOs in many places. This is the primary reason for the workers to feel insecure as the lockdown got extended without an end in sight. If at the beginning of the lockdown, the Government machineries would have geared up, which could have been possible with proper planning as the spread of the virus was at a very primitive stage, the exodus of migrant workers could have been well avoided or at least reduced to a great extent. They would not have felt despair at the turn of events at a later stage. 


\section{WHAT NEEDS TO BE DONE?}

This type of pandemic is a kind of once-in-a-lifetime event for anyone. We do not have to expect this to re-appear any time soon. But this fact should not dither the implementation of better living conditions, especially in rural areas, which could help in reducing the scale of migrant workers.

- The defunct and age-old Act of 1979 should be given the necessary teeth, and its provisions should be modified to suit the modern-day requirement, with a strict intent of compliance.

- Every state government should identify the skill sets of their returnees and support them to improve and get better equipped for the emerging market situations locally.

- Value additions to the rural produce are the need of the hour to generate better revenues and make rural areas self-reliant in their localities.

- The rural population should be encouraged to carry on their traditional economic activities of their native place, which would have been inborn in them for a more skillful display for better economics.

- The current GOI rural job guarantee schemes should be expanded, and the wages of the scheme should be commensurate with the market trend. The GOI should start spending more on rural infrastructure and use the locally available population skills and guarantee the jobs for a greater number of days than that of 100 days a year. The scope of the current scheme shall be reviewed, to be more inclusive so that more employment could be generated at the local level.

- The respective state governments should start properly documenting the Out-migrant population and trace their well-being in the states to which they migrate as in the case of overseas migrant population. This becomes vital to have a proper record of the movement of the people of their state. The migrant workers will also get a sense of security that they have a backup at any emergency.

\section{SCOPE FOR FURTHER STUDIES}

Disserting a situation retrospectively is more convenient, while implementing the appropriate strategies at the time of the real crisis is most important. Migration inside or outside a country is something that cannot be avoided totally. In a way, migration must take place for a better distribution of human resources all around the country for an overall development. This study has concentrated on migrant workers and their plight during COVID-19 lockdown, which is not unique to India. The migrant population, especially the workers, all around the world would have faced similar situations. A study of migrant workers' plight in other countries and how the same was being tackled by their respective governments would give us an opportunity for more exhaustive understanding of things for shaping up the future.

\section{REFERENCES}

[1] Agrawal, T., \& Chandrasekhar, S. (2016). Labour market outcomes of itinerant workers in rural India. Journal of International Development, 28(8), 1251-1271. https://doi.org/10.1002/jid.3126

[2] COVID-19 pandemic lockdown in India, 2020. Wikipedia. Available from: https://en.wikipedia.org/wiki/COVID-19_pandemic_lockdown_in_India

[3] Dhal, M. (2020). Labor Stand: Face of Precarious Migrant Construction Workers in India. Journal of Construction Engineering and Management, 146(6), 04020048. 
https://qz.com/india/1858209/covid-19-lockdown-exposes-indias-looming-migrant-refugeecrisis/

[4] Harish, P. (2020). The Internal and External Migrants together, pose a refugee crisis that India is ill-prepared for. Quartz India. Available from: https://qz.com/india/1858209/covid-19lockdown-exposes-indias-looming-migrant-refugee-crisis/

[5] Bell, M., Charles-Edwards, E., Ueffing, P., Stillwell, J., Kupiszewski, M., \& Kupiszewska, D. (2015). Internal migration and development: Comparing migration intensities around the world. Population and Development Review, 41(1), 33-58. https://doi.org/10.1111/j.17284457.2015.00025.x

[6] Migration, 2001. Office of the Registrar General \& Census Commissioner, India. Ministry of Home Affairs, Government of India. Available from:

https://censusindia.gov.in/Census_And_You/migrations.aspx

[7] Ranjini, B. (2020). Migrant Agricultural Workers in India and the Covid 19 Lockdown. Focus Web. Available from: https://focusweb.org/migrant-agricultural-workers-in-india-and-thecovid-19-lockdown/

[8] Samrat, S. (2019). Around 22\% Indians Live Below Poverty Line; Chhattisgarh, Jharkhand Fare Worst. Financial Express, 21. Available from:

https://www.financialexpress.com/economy/around-22-indians-live-below-poverty-linechattisgarh-jharkhand-fare-worst/1713365/

[9] Supriyo, D. (2019). Internal Migration in India Grows, But Inter-State Movement Remains Low, World Bank Blogs. Available from: https://blogs.worldbank.org/peoplemove/internalmigration-india-grows-inter-state-movements-remain-low 